\title{
Rare cytogenetic abnormalities and their clinical relevance in pediatric acute leukemia of Saudi Arabian population
}

Nawaf Alkhayat ${ }^{1}$, Ghaleb Elyamany ${ }^{2}$, Yasser Elborai ${ }^{1,3}$, Qanita Sedick², Mohammad Alshahrani ${ }^{1}$, Omar Al Sharif ${ }^{1}$, Abdulmalik Alenezy², Amjad Hammdan², Hatem Elghezal², Omar Alsuhaibani², Mansour S. Aljabry ${ }^{4}$, May AlMoshary ${ }^{5}$ and Eman Al Mussaed ${ }^{5 *}$

\begin{abstract}
Background: Childhood Acute Leukemia (AL) is characterized by recurrent genetic aberrations in 60\% of AML cases and $90 \%$ of ALL cases. Insufficient data exists of rare cytogenetic abnormalities in AL. Therefore, we tested rare cytogenetic abnormalities occurring in childhood AL and its effect on clinical prognosis in patients diagnosed at our institution from 2010 to 2017.

Results: Among 150 cases of AL, we detected 9 cases with rare chromosomal abnormalities. We found two hypodiploid (2n-) cases: $2 \mathrm{n}-\mathrm{t}(5 ; 14)(\mathrm{q} 31 ; \mathrm{q} 32)$ and t $(3 ; 11 ; 19)(\mathrm{q} 21 ; \mathrm{q} 23 ; \mathrm{q} 13.1)$ in ALL patients. AML patients showed t (7;14)(q22;q32), t (11; 17)(p15;q21), t (11;20) (p15;q11), t (12;17)(q15;q23) and t (11;20)(p15;q11). Both t $(1 ; 15)(q 10 ; q 10)$ and t $(17 ; 19)(q 21 ; p 13.3)$ occurred in a case with biphenotypic AL. Complete remission (CR) status was attained in 3 patients and 6 patients never attained CR or relapsed/demised.

Conclusion: The study highlighted that rare cytogenetic abnormalities are associated with a poor prognosis. This finding is not well reported in the literature suggesting that ongoing cytogenetic studies for rare abnormalities associated with pediatric leukaemia are warranted.
\end{abstract}

Keywords: Acute leukemia, Rare chromosomal abnormalities, Outcome, Pediatric

\section{Background}

Leukemia is the most common form of pediatric cancer occurring in one-third of childhood malignancies [1].

Acute Leukemia (AL) is a clonal hematological disorder which occurs following a genetic alteration. Acute Lymphoblastic Leukemia (ALL) occurs more frequently in the pediatric age group compared to Acute Myeloid Leukemia (AML) [1].

Cytogenetic investigations using G-banding and fluorescence in-situ hybridization (FISH) is an essential tool for diagnosis, prognosis and targeted therapy. Chromosomal abnormalities are grouped into three prognostic categories: favorable, intermediate and adverse [2]. Some of these abnormalities is common and others are rare.

\footnotetext{
* Correspondence: dreman_almussaed@hotmail.com

${ }^{5}$ Basic Science Department, College of Medicine, Princess Nourah Bint

Abdulrahman University, Riyadh, Kingdom of Saudi Arabia

Full list of author information is available at the end of the article
}

Rare cytogenetic abnormalities that have been described in the literature include aberrations of chromosomes 3 , del $(5 q),-5$ and -7 [3].

While common recurrent cytogenetic abnormalities in AL have been well risk-stratified, the prognostic significance of many rare cytogenetic abnormalities in ALL and AML remains uncertain [4].

There is a paucity of data on the prevalence and clinical outcome of rare cytogenetic abnormalities in the Saudi Arabian population. In this study we have examined rare cytogenetic abnormalities in childhood AL and the clinical outcome.

\section{Materials and methods \\ Patients}

We reviewed 150 cases with a diagnosis of childhood pediatric acute leukemia at Prince Sultan Military Medical City in Riyadh, Saudi Arabia from 2010 to 2017.

(c) The Author(s). 2019 Open Access This article is distributed under the terms of the Creative Commons Attribution 4.0 International License (http://creativecommons.org/licenses/by/4.0/), which permits unrestricted use, distribution, and reproduction in any medium, provided you give appropriate credit to the original author(s) and the source, provide a link to the Creative Commons license, and indicate if changes were made. The Creative Commons Public Domain Dedication waiver (http://creativecommons.org/publicdomain/zero/1.0/) applies to the data made available in this article, unless otherwise stated. 
The diagnosis in all cases was based on morphology, flow cytometry, immunohistochemistry and genetic studies. This study included patients between 1 and 18 years of age (pediatric age group in Saudi Arabia). The medical records were reviewed for all data (Tables 1 and 2).

\section{Cytogenetic analysis and FISH}

Standard cytogenetic preparations were made from bone marrow and/or peripheral blood. Cytogenetic analysis was carried out on G-banding chromosomal preparations in a total of 20 metaphases. Karyotypes were interpreted and reported according to the International System for Cytogenetic Nomenclature [5].

Fluorescence in situ hybridization (FISH) was performed on double stranded DNA in fixed chromosomes using fluorescent probes which bind complementary sequences of mRNA in a sequence of hybridization steps to achieve signal amplification of the target which is viewed using a fluorescent microscope.

The panel of probes used to detect ALL specific abnormalities in our institute are $B C R-A B L: \mathrm{t}(9 ; 22)$, RUNX1-ETV6: t (12;21), MLL gene rearrangements: (11q23), MYC gene rearrangements:(8q24) and TCF3/ PBX1: t (1;19).

The multiprobe AML panel includes: RUNX1/ RUNX1T1: t (8;21), PML /RAR $\alpha$ : (15:17), CBF $\beta$ gene break apart: 16q22, MLL gene break apart, TP53 gene and the $\operatorname{cen}(8,22 \mathrm{q} 11.2)$.

\section{Results}

In our cohort of 150 cases of acute leukemia, we detected 9 cases with rare non-recurrent chromosomal abnormalities of which 4 cases were ALL, 4 cases were AML and one case was biphenotypic AL (B/Myeloid). Two cases with hypodiploidy (2n-), t (5;14) (q31;q32) and $\mathrm{t}(3 ; 11 ; 19)(\mathrm{q} 21 ; \mathrm{q} 23 ; \mathrm{q} 13.1)$ were detected in ALL. The AML patients were found to harbor $\mathrm{t}(7 ; 14)$ (q22; q32), t (11;17)(p15;q21), t (11;20)(p15;q11), t (12;17)(q15; q23) and $t(11 ; 20)(\mathrm{p} 15 ; \mathrm{q} 11)$. Both $\mathrm{t}(1 ; 15)$ (q10; q10) and $t(17 ; 19)$ (q21; p13.3) were detected in the case with biphenotypic AL. The demographic, hematological and cytogenetic data of these 9 cases are summarized in Table 1\& Table 2 and Figs. 1, 2, 3, 4, 5, 6, 7. Complete remission (CR) status was achieved in 3 patients. The

Table 1 Demographic data cases 1-5

\begin{tabular}{|c|c|c|c|c|c|}
\hline Parameter & Case 1 & Case 2 & Case 3 & Case 4 & Case 5 \\
\hline Age (years) & 4 & 7 & 11 & 18 & 3 \\
\hline Gender & Female & Female & Male & Male & Male \\
\hline Clinical & $\begin{array}{l}\text { Cervical Lymphadenopathy } \\
\text { and leucocytosis }\end{array}$ & $\begin{array}{l}\text { Fever, abdominal } \\
\text { distention, } \\
\text { hepatosplenomegaly }\end{array}$ & $\begin{array}{l}\text { Vomiting, diarrhoea, } \\
\text { lower limb weakness }\end{array}$ & $\begin{array}{l}\text { Epistaxis, ecchymosis } \\
\text { skin lesions }\end{array}$ & $\begin{array}{l}\text { Fever, lymphadenopathy } \\
\text { and hepatomegaly }\end{array}$ \\
\hline WBC $\left(10^{9} / \mathrm{L}\right)$ & 137 & 18 & 100,8 & 221 & 18.8 \\
\hline $\mathrm{HB}(\mathrm{g} / \mathrm{dl})$ & 5.2 & 4.8 & 7.2 & 11 & 8.7 \\
\hline PLT (X109/L) & 9 & 53 & 109 & 34 & 239 \\
\hline PB blasts & $80 \%$ & $60 \%$ & No blasts & $40 \%$ & $6 \%$ \\
\hline $\begin{array}{l}\text { Bone marrow } \\
\text { aspirate }\end{array}$ & $\begin{array}{l}\text { Hypercellular Blasts 90\% } \\
\text { B-ALL phenotype }\end{array}$ & $\begin{array}{l}\text { Hypercellular } \\
\text { Blasts } 80 \% \\
\text { B-ALL phenotype }\end{array}$ & $\begin{array}{l}40 \% \text { blasts and } 50 \% \\
\text { eosinophils }\end{array}$ & $\begin{array}{l}40 \% \text { blasts on PB } \\
\text { and } 70 \% \text { blasts on } \\
\text { BM }\end{array}$ & $\begin{array}{l}\text { Hypercellular } \\
\text { Blasts } 75 \% \\
\text { Myelomonocytic } \\
\text { proliferation with M4 } \\
\text { AML }\end{array}$ \\
\hline Blasts & $90 \%$ & $60 \%$ & $40 \%$ & $70 \%$ & $75 \%$ \\
\hline Disease & B-ALL & B-ALL & B-ALL & T-ALL & AML FAB M4 \\
\hline $\begin{array}{l}\text { Cytogenetic } \\
\text { analysis } \\
\text { (karyotype/ } \\
\text { FISH) }\end{array}$ & $\begin{array}{l}46, X X, 1-, 8-, 9-, 11-, 12-, \\
19-, \text { and } 22-\text { in } 80 \% \\
\text { of cells) }\end{array}$ & $\begin{array}{l}\text { 2n-,44, XX, } 4,-8) . \\
\text { t }(12 ; 17) \text {. } \\
\text { ETV/RUNX } 1 . \\
\text { Loss of der (12-) } \\
\text { MYC gene } \\
\text { rearrangement. }\end{array}$ & $\begin{array}{l}\text { t }(5 ; 14) \\
\text { Negative: PDGFRA } \\
\text { PDGFRB FGFR1 }\end{array}$ & $\begin{array}{l}46, X Y, t(3 ; 11 ; 19) \\
(q 21 ; q 23 ; q 13.1) . \\
\text { MLL gene rearranged; } \\
\text { extra MYC gene }\end{array}$ & $\begin{array}{l}48, X Y,+8,+8, t(11 ; 17) \\
\text { (p15;q21) [14]/47, idem,-Y }\end{array}$ \\
\hline Chemotherapy & $\begin{array}{l}\text { Very high risk ALL } \\
\text { chemotherapy protocol } \\
\text { (COG AALL0031) and } \\
\text { intensive consolidation }\end{array}$ & $\begin{array}{l}\text { Standard risk } \\
\text { chemotherapy } \\
\text { protocol (COG } \\
\text { AALL0331). }\end{array}$ & $\begin{array}{l}\text { high-risk protocol } \\
\text { COG AALL0232 } \\
\text { with high dose } \\
\text { methotrexate for } \\
\text { maintenance }\end{array}$ & $\begin{array}{l}\text { Dana Farber then } \\
\text { FLAG-Ida salvage } \\
\text { chemotherapy } \\
\text { high dose }\end{array}$ & MRC AML12 protocol. \\
\hline Survival & Partial remission & $\begin{array}{l}\text { Complete remission } \\
\text { status achieved }\end{array}$ & Complete remission & $\begin{array}{l}\text { Relapsed and } \\
\text { demised }\end{array}$ & $\begin{array}{l}\text { Death due to multiorgan } \\
\text { failure }\end{array}$ \\
\hline
\end{tabular}


Table 2 Demographic data cases 6-9

\begin{tabular}{|c|c|c|c|c|}
\hline Parameter & Case 6 & Case 7 & Case 8 & Case 9 \\
\hline Age (years) & 14 & 18 & 5 & 4 \\
\hline Gender & Male & Male & Male & Male \\
\hline Clinical & $\begin{array}{l}\text { Melena stools, } \\
\text { fatigue }\end{array}$ & $\begin{array}{l}\text { Leucocytosis, anaemia, } \\
\text { thrombocytopenia no } \\
\text { organomegaly }\end{array}$ & $\begin{array}{l}\text { Generalized ecchymosis, } \\
\text { bruises, epistaxis and } \\
\text { hepatomegaly }\end{array}$ & $\begin{array}{l}\text { Fever, malaise } \\
\text { failure to thrive }\end{array}$ \\
\hline WBC (109/L) & 16.5 & 33 & 16.1 & 100 \\
\hline $\mathrm{HB}(\mathrm{g} / \mathrm{dl})$ & 10.1 & 8.2 & 6.7 & 7.8 \\
\hline PLT (X109/L) & 20 & 67 & 14 & 101 \\
\hline PB blasts & $30 \%$ & $70 \%$ & $40 \%$ & $70 \%$ \\
\hline $\begin{array}{l}\text { Bone marrow } \\
\text { aspirate }\end{array}$ & $\begin{array}{l}90 \% \text { blasts with AML } \\
\text { MO morphology }\end{array}$ & $70 \%$ blasts & 40\% blasts With dysplasia & $\begin{array}{l}90 \% \text { blasts comprised } \\
\text { of two distinct } \\
\text { populations }\end{array}$ \\
\hline Blasts & $90 \%$ & $70 \%$ & $40 \%$ & $90 \%$ \\
\hline Disease & AML MO & AML M2 & AML M7 & B/MYELOID \\
\hline $\begin{array}{l}\text { Cytogenetic } \\
\text { analysis } \\
\text { (karyotype/ } \\
\text { FISH) }\end{array}$ & $46, X Y, t(7 ; 14)(q 22 ; q 32)$ & $\begin{array}{l}46, X Y, t(11 ; 20)(p 15 ; q 11) \\
\operatorname{add}(21)(p 11)\end{array}$ & $\begin{array}{l}\mathrm{t}(12 ; 17)(\mathrm{q} 15 ; \mathrm{q} 23) \text {, del(7) } \\
\text { (p15), inv. (8)(q22q24) with } \\
(2+) \text { and(19+) }\end{array}$ & $\begin{array}{l}46, X Y, \operatorname{der}(15) t(1 ; 15) \\
(q 10 ; q 10), \operatorname{der}(17) \\
t(17 ; 19)(q 21 ; p 13.3)\end{array}$ \\
\hline Chemotherapy & $\begin{array}{l}\text { Received induction } \\
(3+7) \text { for } A M L \text { then } \\
\text { high risk MAC/G } \\
\text { protocol }\end{array}$ & $\begin{array}{l}\text { AML induction } \\
\text { chemotherapy }(3+7) \\
\text { protocol. Allogeneic stem } \\
\text { cell transplant with steroid } \\
\text { refractory graft vs host } \\
\text { disease treated with ATG }\end{array}$ & MRC AML12 Protocol & $\begin{array}{l}\text { Received } 7 \\
\text { chemotherapy } \\
\text { cycles }\end{array}$ \\
\hline Survival & $\begin{array}{l}\text { Refractory disease and } \\
\text { demised secondary to } \\
\text { chemotherapy side } \\
\text { effects }\end{array}$ & Complete remission & Patient demised & $\begin{array}{l}\text { Not attain remission } \\
\text { Status. Relapsed for } \\
\text { MUD transplant }\end{array}$ \\
\hline
\end{tabular}

remaining 6 patients never attained CR, relapsed or demised.

\section{Acute lymphoblastic leukemia cases Case 1}

This 4 year old B-ALL patient was negative for ALL panel specific abnormalities with a normal female karyotype (46, XX) (Fig. 1). Hypodiploidy (2n-) with loss of -1 , $-8,-9,-11,-12,-19$ and -22 was detected in $80 \%$ of the studied cells by FISH (Figs. 2, 3, 4, 5). Thereafter, cryptic abnormalities were identified (not detected by the initial karyotyping (Fig. 1). The interesting finding in this case was that the diagnostic karyotype was normal but the FISH showed 2n-. This indicated that FISH revealed the cryptic cytogenetic abnormality which was not detected by GTG-banding karyotype.

The patient was classified on very high risk ALL chemotherapy protocol (COG AALL0031). During induction chemotherapy the patient developed a gluteal ulcer and recurrent infections with positive blood cultures which we treated with antibiotic therapy. The post induction BM aspirate revealed $6 \%$ of blasts with the immunophenotype presentation compatible with partial remission. The patient received 2 weeks of extended induction chemotherapy.
The BM aspirate on day 43 showed morphological remission. Cytogenetics was negative for all detected tumoral clones except for the $2 n$ - which persisted. The patient then received intensified consolidation phase chemotherapy and is currently awaiting BM transplant.

\section{Case 2}

This 7 year old B-ALL patient harbored the classical ETV6 /RUNX1 rearrangement in the majority of analyzed cells. However, a clonal evolution with loss of der (12)- and the MYC gene rearrangement was detected in $20 \%$ of cells. The karyotype showed 44 , XX; del (4); del (8) and t (12; 17) (p13; q21) (Fig. 6).

The patient was classified on standard risk chemotherapy protocol (COG AALL0331). The post induction BMA showed CR. The clinical decision was to continue the chemotherapy protocol in consideration of the mild $2 \mathrm{n}$ - . Hypodiploidy (2n) - < 45 chromosomes is uncommon. Despite improved treatment outcome of childhood ALL, patients with hypodiploid ALL have a dismal prognosis [6-8].

\section{Case 3}

This 11 year old patient presented with vomiting, diarrhea and generalized weakness for 3 weeks. The full blood 


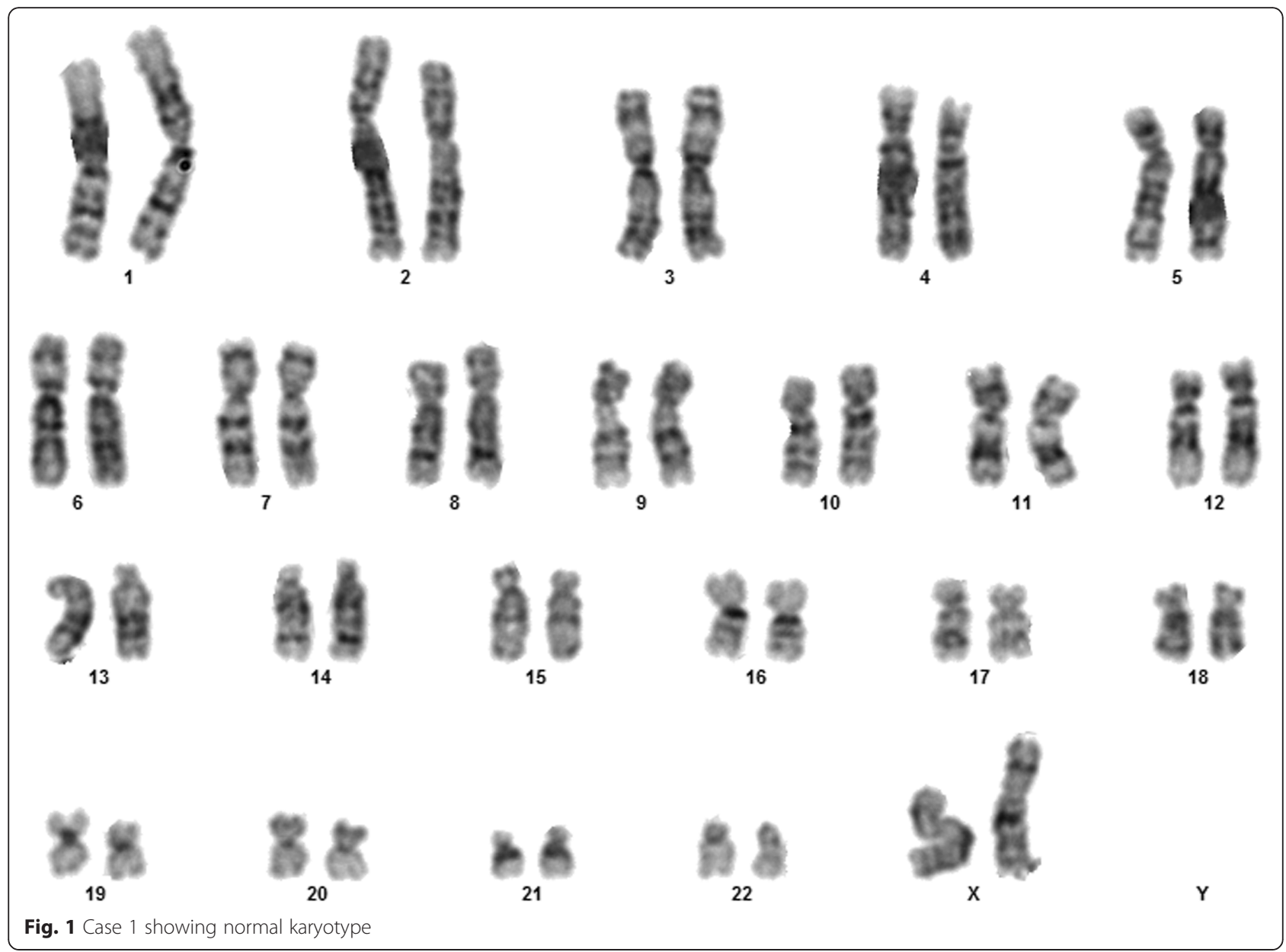

count detected leukocytosis with marked eosinophilia. The BM was hypercellular with eosinophilia (50\%) (Fig. 7) and blasts (40\%) (Fig. 8) with B-ALL immunophenotype. The cytogenetic and molecular analysis detected $\mathrm{t}(5 ; 14)$ (q31; q32) by FISH. RT-PCR was negative for PDGFRA,

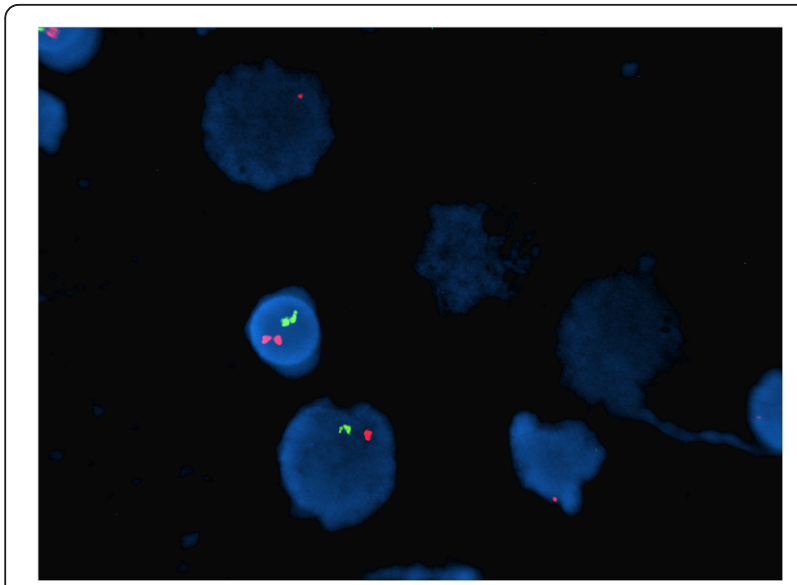

Fig. 2 Case $1 \mathrm{FISH}$ showing $2 \mathrm{n}$ - in $B C R-A B L$ probe (monosomy 9 and 22)
PDGFRB, and FGFR1 gene abnormalities. We diagnosed the patient with concurrent B-ALL and hypereosinophilia.

The patient was classified on steroid therapy and on high-risk chemotherapy at the time of diagnosis. Post induction chemotherapy analysis showed morphological $<<$

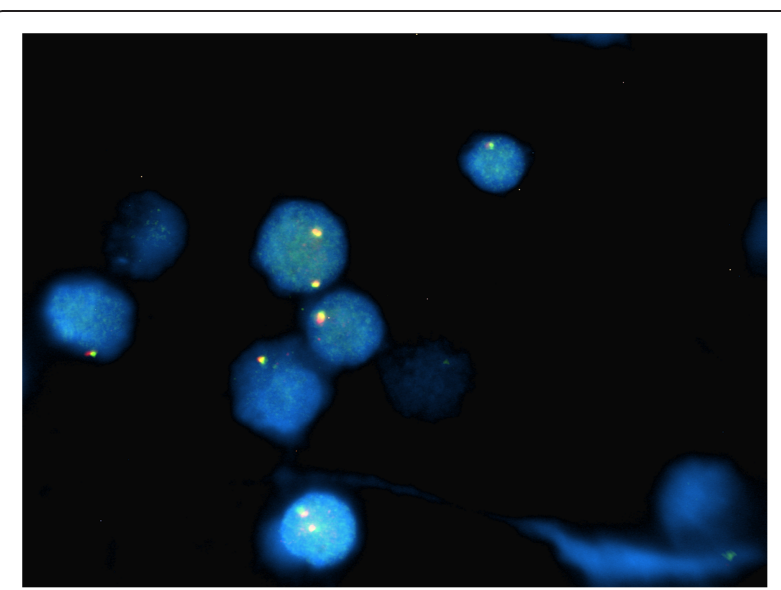

Fig. 3 Case 1 FISH showing 2 n- in MYC probe (monosomy 8) 


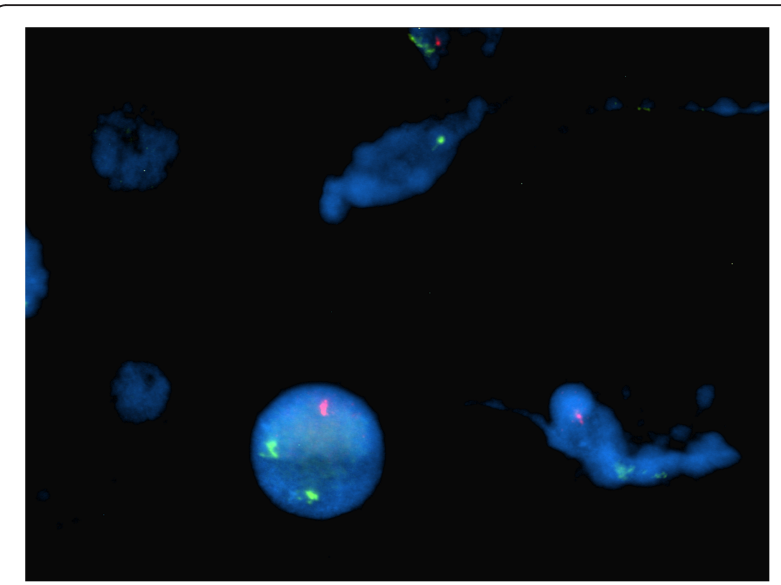

Fig. 4 Case 1 FISH showing 2n- in MLL probe

3\% blasts/ no eosinophil's in the BM) and molecular (negative IGH gene rearrangements) remission. The patient is currently in CR status on high dose methotrexate therapy for maintenance.

The $t(5,14)$ in association with eosinophilia has not been frequently reported in the literature. A single case report of a 6 year old boy presenting with hypereosinophilia and associated Loeffler endocarditis has been previously recorded [8]. Three months following his initial hypereosinophilia this patient developed cutaneous B-lymphoblastic lymphoma. Reanalysis of apparently uninvolved BM revealed a single, previously unidentified.

t $(5 ; 14)$ (q31; q32) positive cell. IL3 / IGH @ fusion were demonstrated in cutaneous lymphoma cells. Our patient also showed the IL3/IGH gene translocation strengthening the association of IL3 hypersecretion and hypereosinophilia [8].

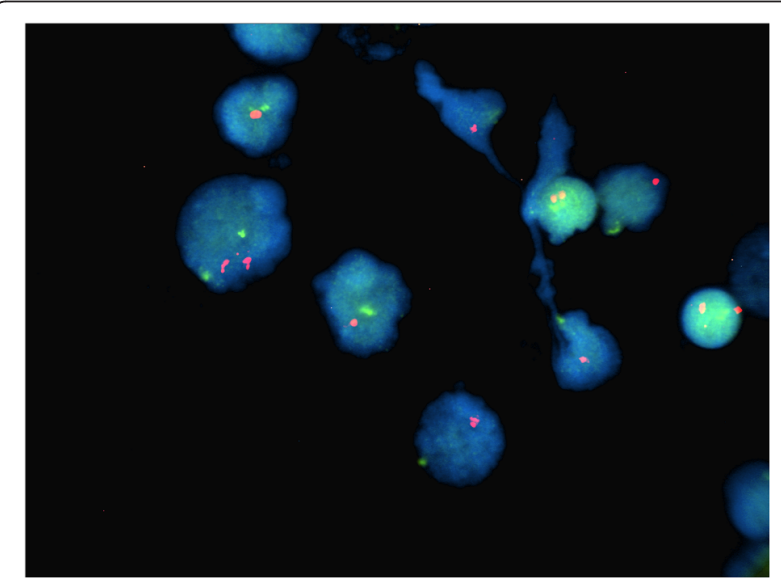

Fig. 5 Case 1 FISH showing 2n- in ETV6-RUNX1 probe

\section{Case 4}

This 18 year old T-ALL patient presented with the typical $\mathrm{T}$ cell immunophenotype on $40 \%$ of blasts (CD45 dim, CD4, CD8, CD7, CD5, CD2, CD38, CD34, cCD3). The karyotype was 46,XY; t (3;11;19)(q21;q23; q13.1) (Fig. 9). FISH was positive for $M L L$ gene rearrangement (Fig. 10). An extra copy of the MYC gene was detected in $40 \%$ of the studied cells (Fig. 11).

The patient was classified on DANA FARBER protocol but did not respond. FLAG-IDA salvage chemotherapy high dose was started. The patient, however, never attained $\mathrm{CR}$ and subsequently demised. To the best of our knowledge, this is the first case reported in the literature harboring this complex translocation.

\section{Acute myeloid leukemia cases}

\section{Case 5}

This 3 year old AML M4 patient showed $\mathrm{t}(11 ; 17)$ (p15; q21), tetrasomy (4n) of chromosome 8 and two extra copies of MYC in 85 and $70 \%$ of the studied cells (Fig. 12).

The patient was classified on the first cycle of MRC AML12 protocol. On day 5 post chemotherapy the patient developed neutropenia and persistent high grade fever. The patient was given Vancomycin and Amikacin following blood cultures and Meropenem for a urinary tract infection. Prophylactic fluconazole was started. On the final chemotherapy cycle the patient developed bloody diarrhea and abdominal distention. The abdominal ultrasound and CT Abdomen revealed a severe typhilitis. Despite intensive care support, the patient demised following cardiopulmonary arrest and multi-organ failure one month after admission.

Only 3 cases of pediatric AML with the t $(11 ; 17)(\mathrm{p} 15$; q21) have been previously reported: two AML M4 cases (aged 3 and 4 years) one AML M0 case [9-11]. Another MDS case with isolated $t(11 ; 17)(\mathrm{p} 15 ; \mathrm{q} 21)$ after neuroblastoma chemotherapy has been reported in an 8 years old girl [12]. In adults, the translocation has been reported in one case [12].

\section{Case 6}

This 14year old patient was diagnosed with Hodgkin's Lymphoma (HL) stage 3-A and was in remission for 5 years. The patient was treated with ABVD and CHIVPP. He arrived at the Emergency Unit with the clinical symptoms of melena stools, fever, fatigue, lymphadenopathy and hepatosplenomegaly. The BM and immunophenotype was compatible with AML MO. A lymph node biopsy showed a myeloid sarcoma. 


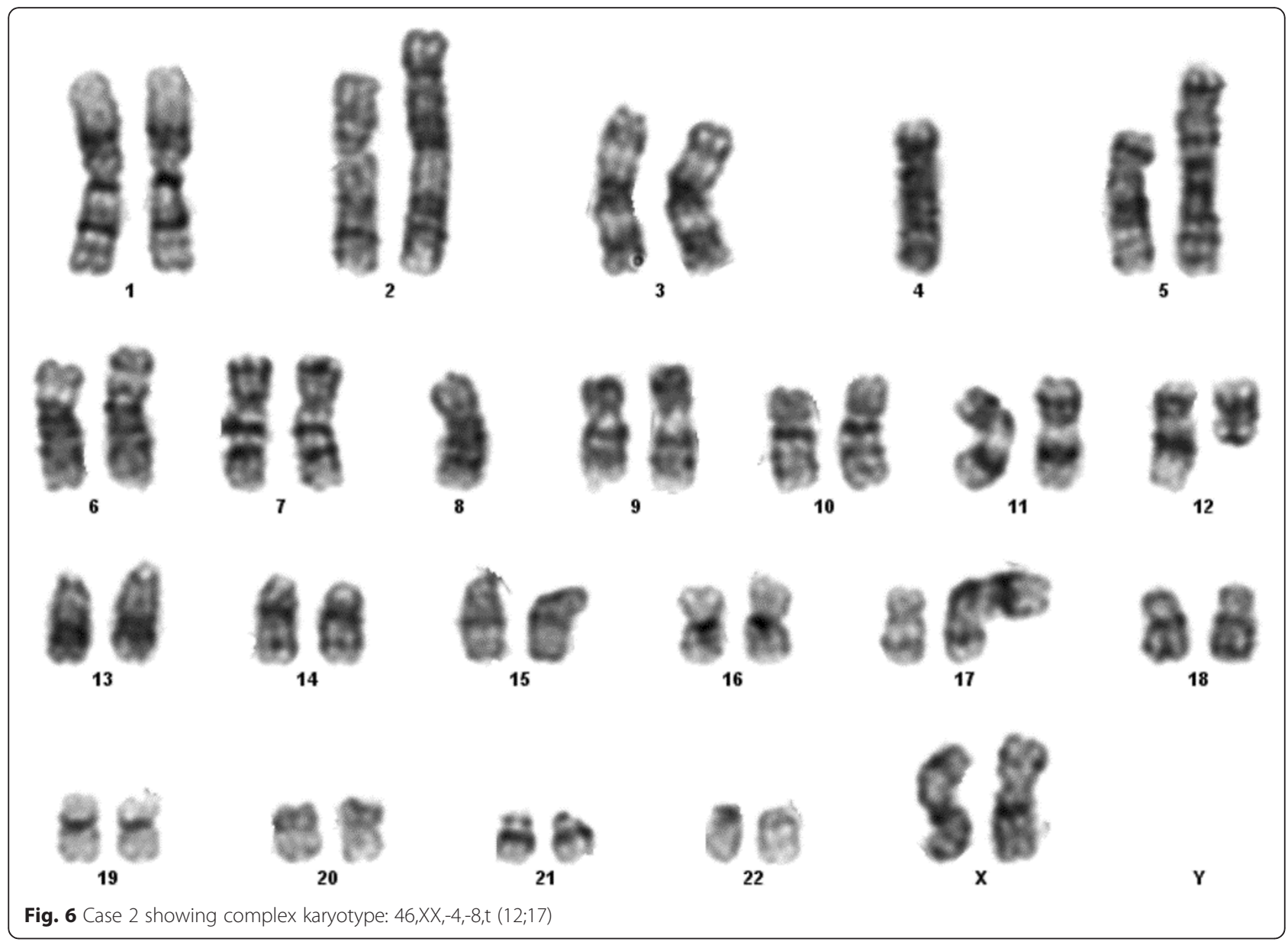

Chromosomal analysis detected the karyotype 46, $\mathrm{XY}, \mathrm{t}(7 ; 14)$ (q22; q32). FISH was negative for AML panel specific abnormalities. After initiation of induction chemotherapy the patient developed persistent neutropenia with klebsiella infection and did not attain

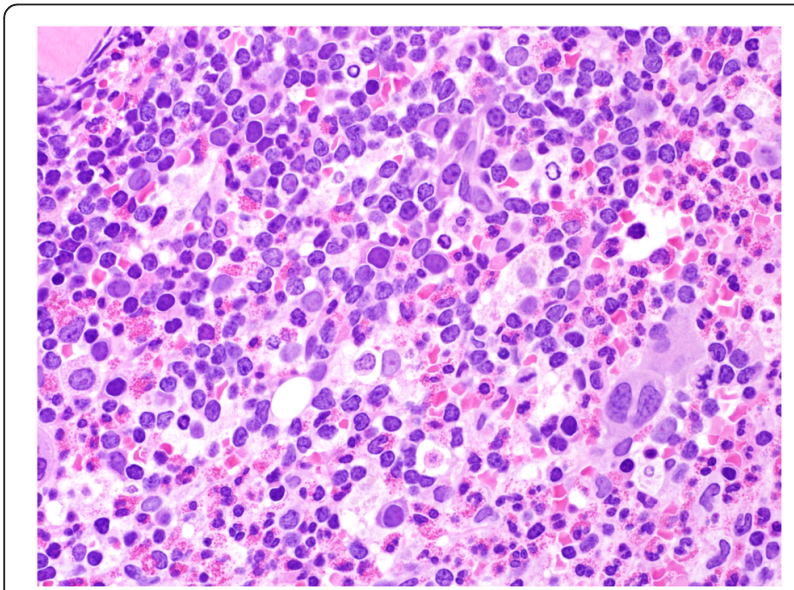

Fig. 7 Case 3 hematoxylin and eosin stain shows prominent eosinophilia remission status. He was classified on high risk MAC/ $\mathrm{G}$ protocol. He continued to have chemotherapy related side effects such as afebrile neutropenia, severe mucositis and multiple resistant bacterial and fungal infections. The patient failed to recover or attain remission status and subsequently demised. This is rare

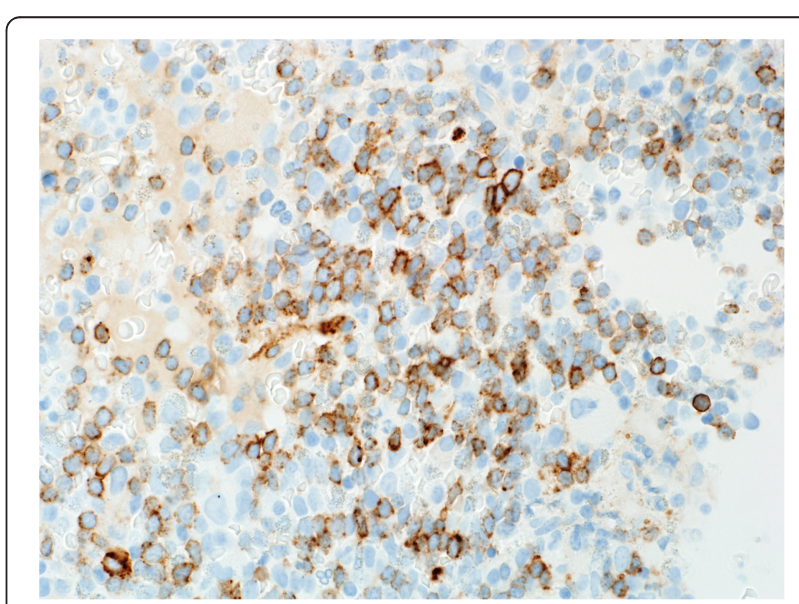

Fig. 8 Case 3 shows CD34+ blasts on immunohistochemistry 


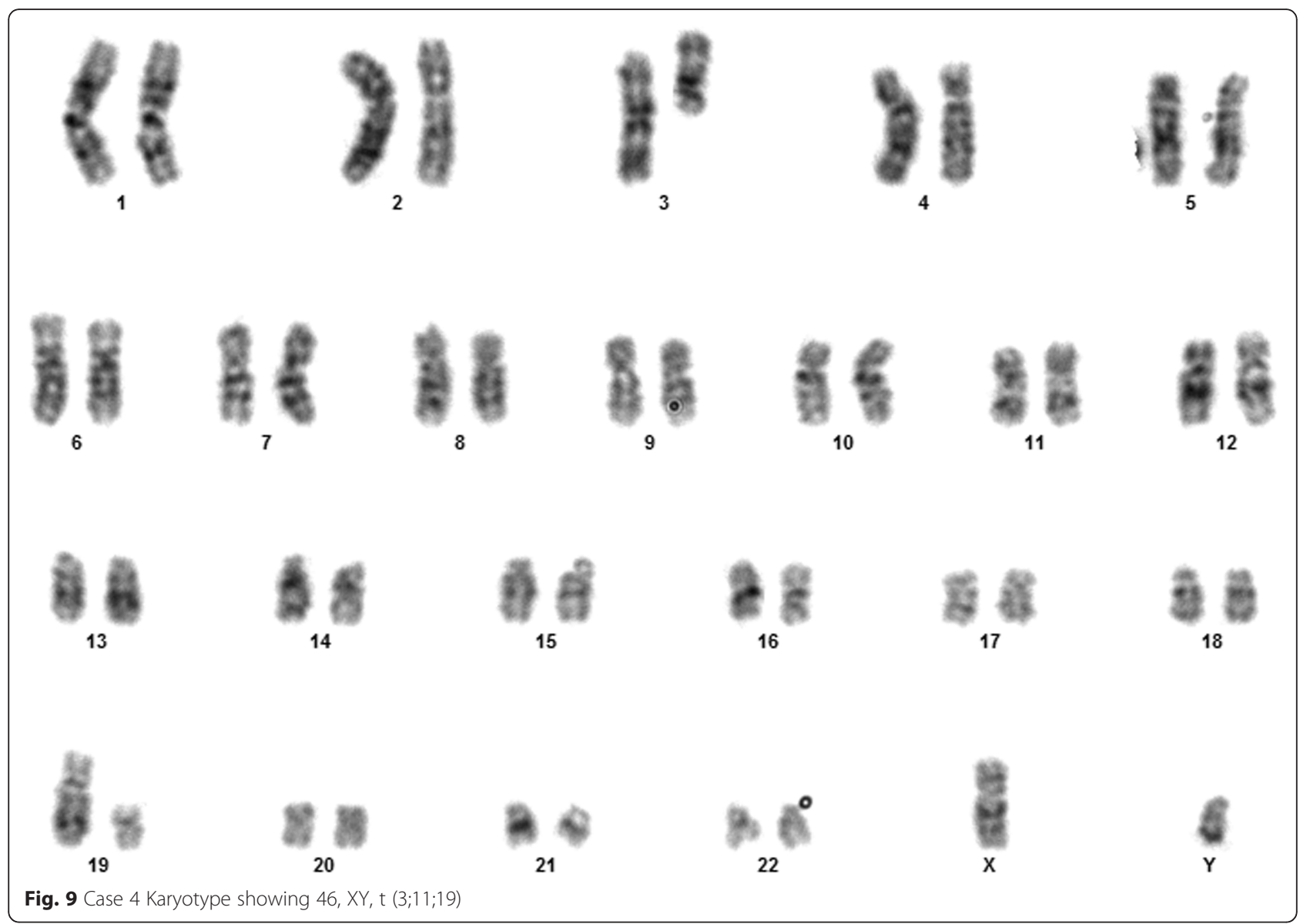

presentation of AML MO with $\mathrm{t}(7,14)$ in a patient with previous HL.

Secondary leukemia's as in this patient commonly manifest with abnormalities of chromosome 7 and 5, however, the $\mathrm{t}(7 ; 14)$ (q22; q32) commonly occurs in TALL and rarely in AML $[13,14]$.

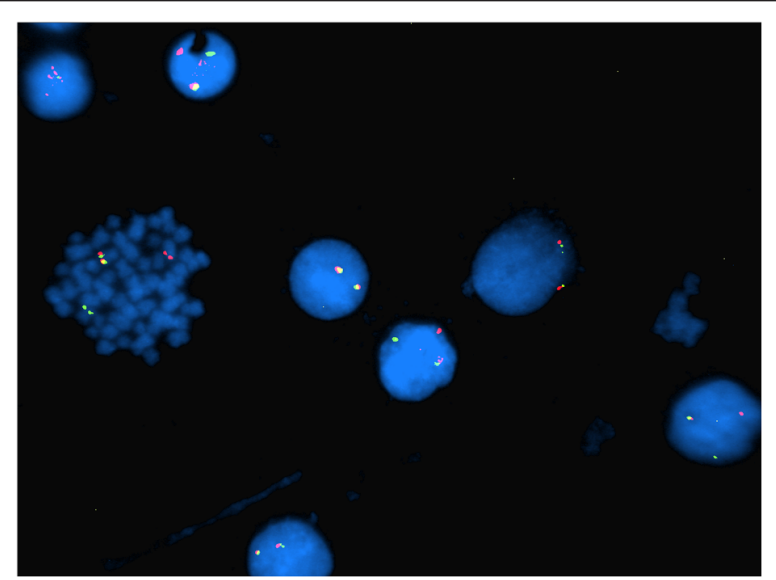

Fig. 10 Case 4 FISH showing MLL gene rearrangement

\section{Case 7}

This 18 year old patient was diagnosed as AML (M2) both morphologically and immunophenotypically. Aberrant expression of CD7 occurred on a cellular subpopulation. Cytogenetic analysis showed 46, XY; t $(11,20)$ (p15; q11) and add (21) (p11) (Fig. 13). The patient

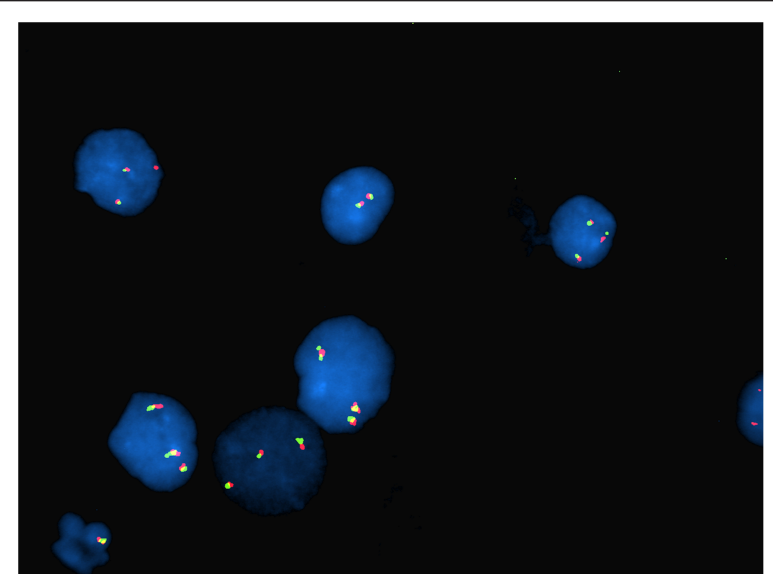

Fig. 11 Case 4 FISH showing extra copy of MYC gene 


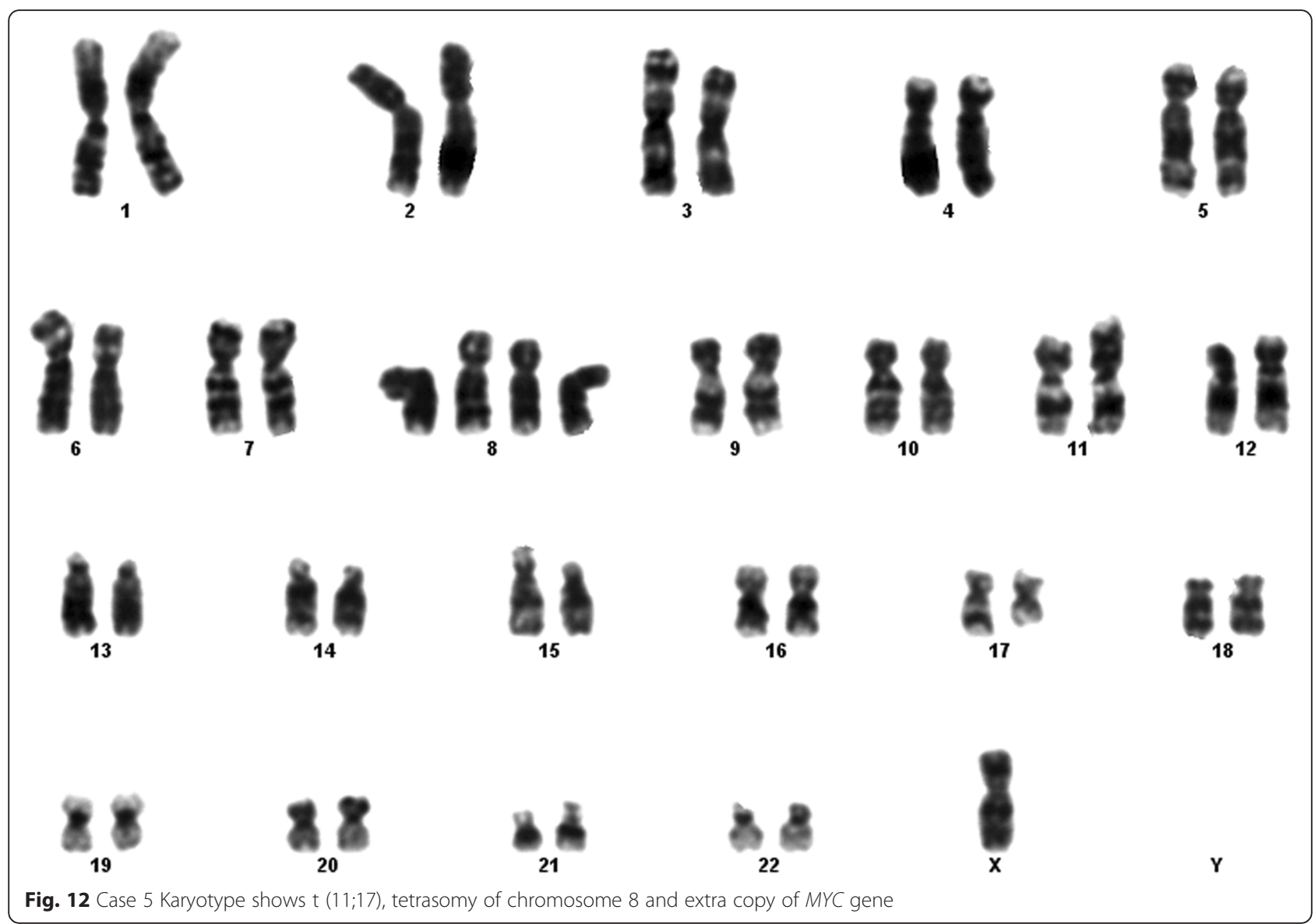

started the first cycle of AML induction chemotherapy $(3+7)$ protocol and achieved CR.

This $\mathrm{t}(11 ; 20)(\mathrm{p} 15 ; \mathrm{q} 11)$ is a rare chromosomal translocation which has a poor prognosis $[15,16]$. Our case responded well to $3+7$ protocol ( 3 doses of Daunorubicin +7 days of cytosine arabinoside) and attained CR. The patient then had allogeneic stem cell transplant and later developed steroid refractory graft versus host disease which was treated with ATGA.

\section{Case 8}

This 5 year old patient presented with anemia and thrombocytopenia. He received IVIG infusion as ITP (immune thrombocytopenic purpura) was suspected, but no improvement occurred. A BM aspirate immunophenotype was compatible with AML (FAB; M7). The cytogenetic analysis revealed a complex karyotype t $(12 ; 17)(\mathrm{q} 15 ; \mathrm{q} 23)$ and $48, \mathrm{XY},+2$, del (7)(p15), inv. (8)(q22q24), t (12;17) (q15;q23) and trisomy 19. FISH reported PML/RARA; RUNX1 / RUNX1T1; (5'CBFB, (3'CBFB, 5'CBFB con 3'CBFB) / (5'MLL (3'MLL, 5'MLL con $\left.3^{\prime} M L L\right)$. In addition, a tumoral clone with extra chromosome (2+) and (19+), del (7p), inv.(8) and $t$ (12; 17) (Fig. 14) was detected.

The patient was treated on MRC AML12 Protocol but did not attain remission and subsequently demised. This very rare $t(12 ; 17)$ has been reported in three adults and one child with secondary AML [17, 18]. Interestingly, the four published cases have been female and have additional aberrations. Our patient is male and the translocation is also part of a complex karyotype.

\section{Case 9}

This 4 year old patient was diagnosed as biphenotypic acute leukemia (B /Myeloid). Morphology of two morphologically diverse populations of cells immunophenotypically expressed myeloid markers (CD13, CD33 and MPO) and B cell markers (CD10, CD19, CD79a, and $\mathrm{TdT}$ ).

The cytogenetic analysis revealed the presence of a cell line with der $\mathrm{t}(1 ; 15))(1 \mathrm{q} 10 ; 15 \mathrm{q} 10)$ and $\mathrm{t}$ (17q21; 19p13.3). The FISH panel was negative for all gene abnormalities. 


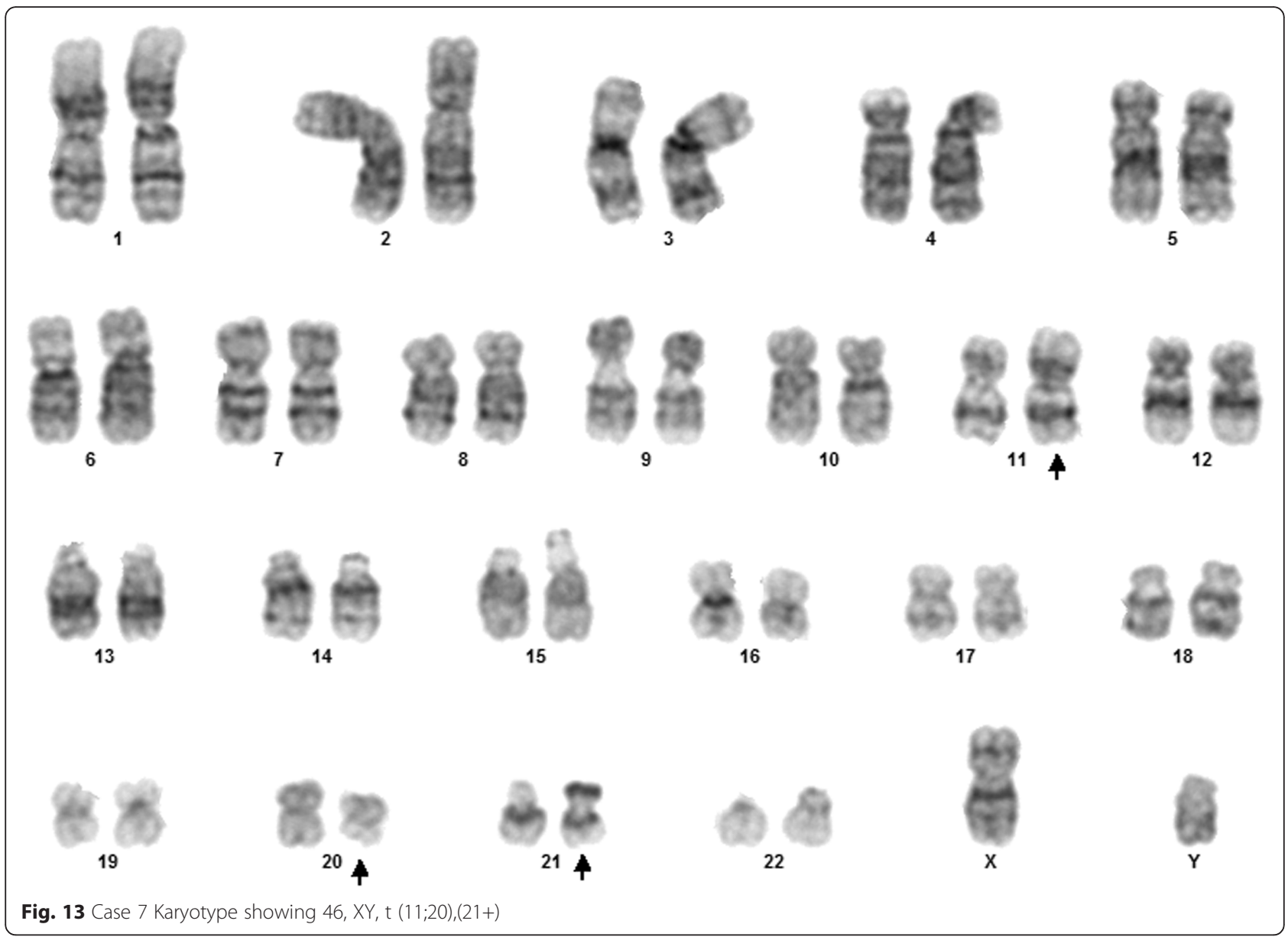

We diagnosed a biphenotypic (B /Myeloid) leukemia with the rare $\mathrm{t}(1 ; 15)$ present in the AML clone and $\mathrm{t}(17 ; 19)$ present in the B-ALL clone. The patient was classified on MRC AML12 protocol. The post induction BM showed persistent disease (60\% blasts). A second $\mathrm{ADE}$ was given and the $\mathrm{BM}$ showed a regenerating marrow with $5 \%$ clonal blasts. A third cycle of the protocol MACE and fourth cycle CLASP were given and samples were taken for matched unrelated donor transplant. During the fourth chemotherapy cycle, the patient developed septic shock and the protocol was changed to a fifth chemotherapy cycle MidAC. A month after completing this cycle, the patient presented with fever, bone aches and neutropenia with circulating blasts. The BM aspirate showed relapse with $60 \%$ blasts. The patient was classified on FLAG-IDA (the sixth chemotherapy protocol). However, the patient remained refractory. In addition, the patient developed febrile neutropenia and was started on antibiotics, antifungal therapy and a 7th course of chemotherapy. A matched unrelated donor transplant was planned by the treating physicians in view of the persistent refractory disease.

\section{Discussion}

Cytogenetic investigations for chromosomal abnormalities are important tools for classification and prognostic determination in AL [19]. Response to chemotherapy in $\mathrm{AL}$ depends on the cytogenetic characteristics and patient's age [2]. Leukemia's with adverse cytogenetic abnormalities and older patients are associated with a poor prognosis [3].

While studies showing the prognostic significance of rare cytogenetic abnormalities in adults have been reported in large cohorts [5], there is a paucity of data showing this association in the pediatric population.

We studied a large series of pediatric patients with acute leukaemia in Saudi Arabia through GTG-banding and FISH techniques. We found that 9 of these cases harbored rare (non-recurrent) chromosomal abnormalities. We analyzed them and found correlations with regard to clinical presentation, outcome and cytogenetic abnormalities.

\section{Conclusion}

Our results confirm that rare cytogenetic chromosomal abnormalities in pediatric AL are associated with a poor 


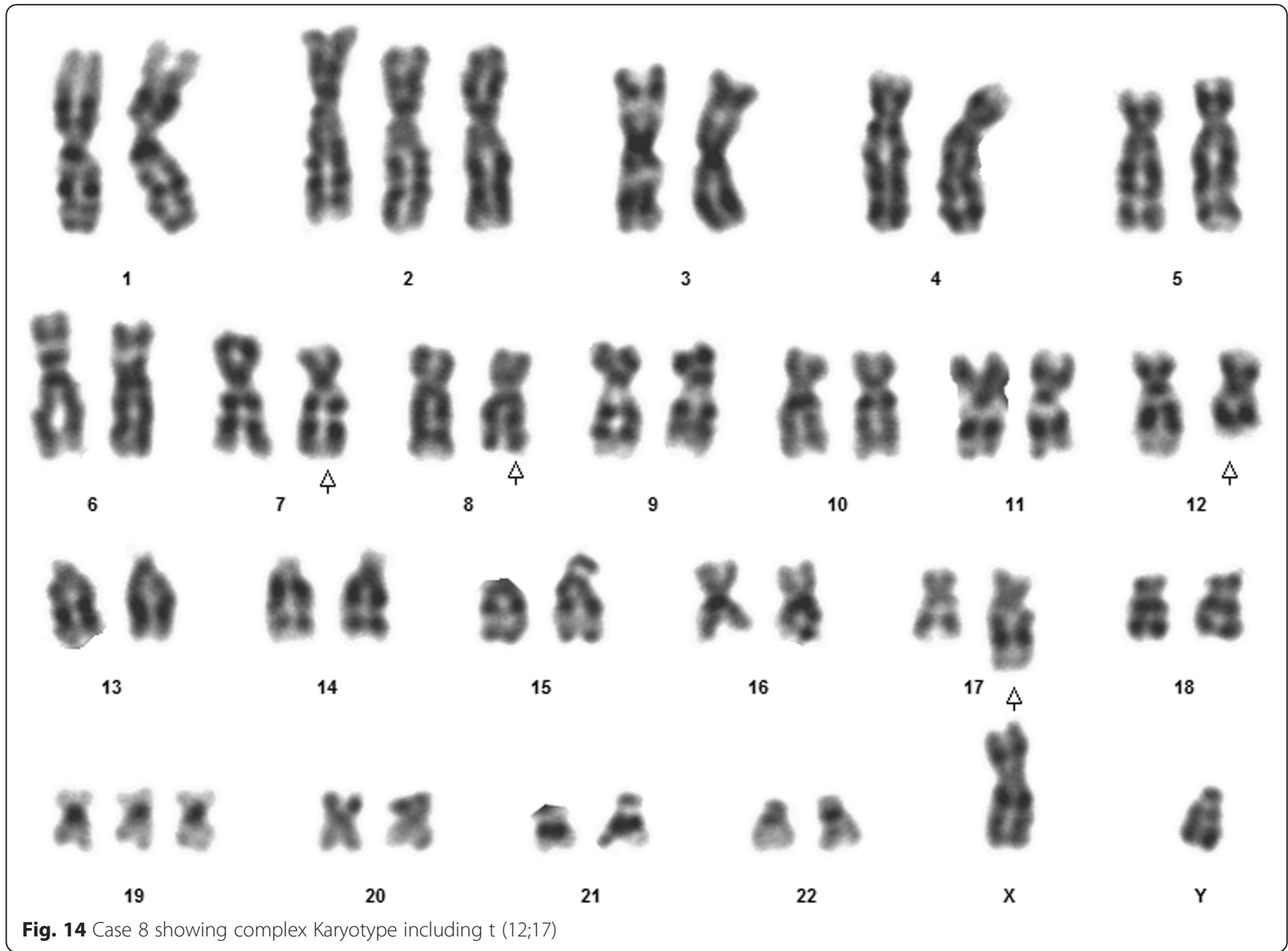

outcome. Data confirming these findings are sparsely reported in the literature suggesting that ongoing cytogenetic studies are warranted in larger groups of AL to identify rare and novel chromosomal abnormalities that may contribute to diagnosis and prognosis in pediatric patients with AL and help in the development of targeted therapeutic drugs.

\section{Abbreviations}

AL: Acute leukemia; ALL: Acute lymphocytic leukemia; AML: Acute myeloid leukemia; BM: Bone marrow; ChIVPP/ABWP: Chlorambucil, vinblastine, procarbazine, doxorubicin, bleomycin, vincristine and etoposide; CLASP: Cytarabine plus L-asparaginase; COG: Children's Oncology Group; CR: Complete remission; FISH: Fluorescence in situ hybridization; FLAG: Fludarabine + high dose AraC + GCSF; IDA: Idarubicin; MACE: Amsacrine + AraC +etoposide; MidAC: Mitoxantrone and AraC; MRC: Medical Research Council; RT-PCR: Reverse transcription polymerase chain reaction

\section{Acknowledgements}

Not applicable.

\section{Ethics and approval and consent to participate}

Ethics for this study complies with the Declaration of Helsinski and is conducted under the auspices of the Saudi Arabian Pediatric Hematology/ Oncology Society (SAPHOS).

\section{Authors' contributions}

All authors contributed to this manuscript accordingly.All authors read and approved the final manuscript

\section{Funding}

The authors disclosed receipt of the following financial support for the research, authorship, and/or publication of this article: This work was supported by SANAD Children's Cancer Support. Association and SANAD Research Grants Program (Grant Number: RGP-2015-06).

\section{Availability of data and materials}

All data generated or analyzed during this study are included in this article and its supplementary material.

\section{Consent for publication}

Not applicable.

\section{Competing interests}

The authors declare that they have no competing interests.

\section{Author details}

${ }^{1}$ Department of Pediatric Hematology/Oncology, Prince Sultan Military Medical City, Riyadh, Saudi Arabia. ${ }^{2}$ Department of Central Military Laboratory and Blood Bank, Prince Sultan Military Medical City, Riyadh, Saudi Arabia. ${ }^{3}$ Department of Pediatric Oncology, National Cancer Institute, Cairo University, Cairo, Egypt. ${ }^{4}$ Department of Pathology, Hematology unit, King Khalid University Hospital, King Saud University, Riyadh, Kingdom of Saudi Arabia. ${ }^{5}$ Basic Science Department, College of Medicine, Princess Nourah Bint Abdulrahman University, Riyadh, Kingdom of Saudi Arabia. 
Received: 31 May 2019 Accepted: 4 September 2019

Published online: 11 October 2019

\section{References}

1. Manola KN. Cytogenetics of pediatric acute myeloid leukemia. Eur J Haematol. 2009:83:391-405.

2. Betts DR, Ammann RA, Hirt A, Hengartner H, Beck-Popovix M. The prognostic significance of cytogenetic aberrations in childhood acute myeloid leukemia. A study of the Swiss Paediatric oncology group (SPOG). Eur J Haematology, Jun. 2007;78(6):468-76.

3. Shahjahani M, Khodadi E, Seghatoleslami M, et al. Rare cytogenetic abnormalities and alteration of microRNAs in acute myeloid leukemia and response to therapy. Oncol Rev. 2015;9(1):261.

4. Grimwade D, Hills RK, Moorman AV, Walker H, Chatters S, Goldstone AH, Wheatley K, Harrison CJ, Alan K. Burnett on behalf of the National Cancer Research Institute adult leukemia working group. Refinement of cytogenetic classification in acute myeloid leukemia: determination of prognostic significance of rare recurring chromosomal abnormalities among 5876 younger adult patients treated in the United Kingdom Medical Research Council trials. Blood. 2010;116:354-65.

5. ISCN 2016: An international system for human Cytogenomic nomenclature (2016): cytogenetic and genome research 2016, vol. 149. p. 1-2.

6. Nachman JB, Heerema NA, Sather H, Camitta B, Forestier E, Harrison CJ, Dastugue N, Schrappe M, Pui C-H, Basso G, Silverman LB, Janka-Schaub GE. Outcome of treatment in children with hypodiploid acute lymphoblastic leukemia. Blood. 2007;110:1112-5.

7. Pui CH, Yang JJ, Hunger SP, et al. Childhood acute lymphoblastic leukemia: progressive through collaboration. J Clin Oncol. 2015;33(27):2938-48.

8. Harrison CJ, Moorman AV, Broadfield ZJ, et al. Three distinct subgroups of hypodiploidy in acute lymphoblastic leukaemia. Br J Haematol. 2004;125:522-59.

9. Bamken S, Haigh S, Bown N, Carey P, Wood K, Windebank K. Cutaneous Blymphoblastic lymphoma with IL3/lgH translocation presenting with hypereosinophilia and acute endocarditis. Pediatr J Blood Cancer. 2015 Jun; 62(6):1055-7.

10. Kerndrup GB, Kjeldsen E. Acute leukemia cytogenetics: an evaluation of combining G-band karyotyping with multi-color spectral karyotyping. Cancer Genet Cytogenet. 2001 Jan 1;124(1):7-11

11. Forestier E, Heim S, Blennow E, Borgström G, Holmgren G, Heinonen K, Johannsson J, Kerndrup G, Andersen MK, Lundin C, Nordgren A, Rosenquist R, Swolin B, Johansson B. Nordic Society of Paediatric Haematology and Oncology (NOPHO); Swedish Cytogenetic Leukaemia Study Group (SCLSG); NOPHO Leukaemia Cytogenetic Study Group (NLCSG). Cytogenetic abnormalities in childhood acute myeloid leukaemia: a Nordic series comprising all children enrolled in the NOPHO-93-AML trial between 1993 and 2001. Br J Haematol. 2003;121(4):566-77.

12. Nishiyama M, Arai $Y$, Tsunematsu $Y$, Kobayashi $H$, Asami $K$, Yabe M, Kato $S$, Oda M, Eguchi H, Ohki M, Kaneko Y. 11p15 translocations involving the NUP98 gene in childhood therapy-related acute myeloid leukemia/ myelodysplastic syndrome. Genes Chromosomes Cancer. 1999;26(3):215-20.

13. Duployez N, Struski S, Roche-Lestienne C. t $(11 ; 17)$ (p15; q21) involving the NUP98 gene is a rare event in adult acute myeloid leukemia. Atlas Genet Cytogenet Oncol Haematol. 2016;20(2):96-7.

14. Raimondi SC, Kalwinsky DK, Hayashi Y, Behm FG, Mirro J Jr, Williams DL. Cytogenetics of childhood acute nonlymphocytic leukemia. Cancer Genet Cytogenet. 1989;40(1):13-27.

15. Strehl S, König M, Mann G, Haas OA. Multiplex reverse transcriptasepolymerase chain reaction screening in childhood acute myeloblastic leukemia. Blood. 2001 Feb 1;97(3):805-8.

16. Lam DH, Aplan PD. NUP98 gene fusions in hematologic malignancies Leukemia. 2001;15:1689-95.

17. Ganguly BB, Loher $Y$, Agarwal MB. Translocation t (11; 20) (p15; q11) detected in AML MO: a case report. Atlas Genet Cytogenet Oncol Haematol. 2008;12:1.

18. Betts D. t (12; 17) (p11; q11) in AMLAtlas Genet Cytogenetic Onco Haematol. 2007;11(2):135.

19. Hasserjian RP. Acute myeloid leukemia: advances in diagnosis and classification. Int J Lab Hematol. 2013:35:358-66.

\section{Publisher's Note}

Springer Nature remains neutral with regard to jurisdictional claims in published maps and institutional affiliations.

Ready to submit your research? Choose BMC and benefit from:

- fast, convenient online submission

- thorough peer review by experienced researchers in your field

- rapid publication on acceptance

- support for research data, including large and complex data types

- gold Open Access which fosters wider collaboration and increased citations

- maximum visibility for your research: over $100 \mathrm{M}$ website views per year

At $\mathrm{BMC}$, research is always in progress.

Learn more biomedcentral.com/submissions 